\title{
O EPICURISMO DE ERASMO
}

\author{
Erasmus's Epicurism
}

\author{
Luiz Paulo Rouanet
}

Doutor em Filosofia pela Universidade de São Paulo. Professor PUC-Campinas.

e-mail: lrouanet@terra.com.br

"O que estou dizendo não é para a multidão, mas para ti, já que somos um para o outro um teatro suficientemente grande" (Epicuro, apud Sêneca). ${ }^{1}$

\section{Resumo}

Erasmo de Roterdã é um autor que pode ser qualificado de ironista, pois cultiva, acima de tudo, o bom humor. Seus Colóquios são fonte inesgotável de ditos espirituosos e cenas cômicas e satíricas. Erasmo disse que não suportaria ser torturado por suas convicções religiosas e rejeitou a oferta de Lutero para que se convertesse ao Luteranismo. Neste texto, abordaremos estas e outras questões, relacionando-os com alguns dos ensinamentos de Epicuro.

Palavras-chave: Erasmo; Epicuro; Comédia; Ironismo.

Citado por MORAES, João Q. de. Epicuro - As luzes da ética. São Paulo: Moderna, 1998. p. 101. 


\section{Abstract}

Erasmus is an author whom we may call ironist, since his main characteristic is humour. His Colloquies are an unending source of witticisms and comic and satiric scenes. Erasmus was unwilling to submit to torture on account of his religious convictions and rejected the offer by Luther to be converted to Lutheranism. In this paper, we shall discuss these matters, relating them to some of Epicure's teachings.

Keywords: Erasmus; Epicurus; Comedy; Ironism.

\section{Introdução}

Ao enfatizar, no título, o epicurismo de Erasmo (1467-1537), indico que se trata de estudar a manifestação do pensamento de Epicuro no humanista do século XVI, e não aprofundar-me no pensamento do filósofo grego. No entanto, é importante tentar separar a concepção que tem Erasmo desse pensamento daquele que efetivamente pode ser atribuído, com base em nossas informações atuais, ao pensador da Antigüidade.

Embora se possa discernir no pensamento de Erasmo como um todo, e particularmente nos Colóquios e Adágios, a forte influência de Epicuro, dada a enorme abrangência da obra do pensador humanista, irei centrar-me no texto em que essa filiação é explicitamente - o tão explícito quanto possa ficar em um texto que assume a forma do diálogo - assumida: o colóquio O epicurista (CHOMARAT, 1992). Eventualmente, referir-me-ei a outros textos. ${ }^{2}$

Em um segundo momento, irei expor as principais teses de Epicuro, notadamente no que concerne à ética, a fim de comparar com as posições epicuristas assumidas pelo texto de Erasmo.

Por fim, irei examinar, no âmbito do pensamento mais abrangente de Erasmo, a justificativa para considerá-lo como filósofo epicurista, ainda que seu epicurismo assuma uma forma peculiar, na qual é combinado com o

2 Efetuei um exame mais extenso da obra de Erasmo, mas abordando especificamente o tema da paz, em minha tese de doutorado, ROUANET, Luis P. O enigma e o espelho: Uma análise dos discursos sobre a paz de Erasmo e Rawls. 2000. 227f. tese (Doutorado em filosofia) FFLCH - USP, 2000. 
cristianismo, assumido e jamais renegado pelo pensador renascentista. Procurarei avaliar, então, em linhas gerais, qual a pertinência dessa aproximação entre as duas correntes de pensamento.

\section{O epicurista}

O colóquio $\mathbf{O}$ epicurista consiste em um diálogo que se passa em lugar não especificado, entre dois personagens, Hedon e Espudeus. ${ }^{3}$ Trata-se do último colóquio escrito por Erasmo, datado de 1533. Não seria sua profissão última de fé? No texto, ao mesmo tempo que assume o epicurismo como a escola de pensamento de sua preferência (Hedon: Quanto a mim, é a escola de Epicuro que mais me agrada.), ${ }_{4}^{4}$ procura conciliá-lo com o cristianismo. Quanto a Espudeus, no início do colóquio está lendo o livro de Cícero De finibus. Pode-se supor que o colóquio busque efetuar uma defesa do epicurismo contra os ataques de Cícero, em especial, tomando-o como principal crítico do filósofo grego. Sabe-se que Santo Agostinho foi outro de seus críticos importantes, mas, obviamente, Erasmo não ousará contrapor-se ao doutor da Igreja, escolhendo como alvo um adversário pagão. Tendo chegado à idade avançada (Erasmo tem, então, 66 anos), não porá em risco sua segurança, como prega, aliás, a própria doutrina epicurista. Quando Lutero pediu-lhe que aderisse à sua causa, Erasmo respondeu que, sendo por natureza afeito aos prazeres e avesso às dores, não suportaria ser torturado por questões de fé. ${ }^{5}$

Espudeus manifesta sua preferência pela filosofia estóica, seguida pela dos peripatéticos, ou aristotélicos: "A meu ver, [...] os estóicos são os menos afastados da verdade, seguidos de perto pelos peripatéticos" (p. 373).

3 Em francês, Hédon e Spudée, e em latim Hedonius (aquele que busca o prazer) e Spudaeus (o homem sério).

4 L'épicurien, in Erasme, Oeuvres, C. Blum, A. Godin, J. C. Margolin, D. Ménager, Paris, Laffont, "Bouquins", 1992 (contient l'Éloge de la Folie, un choix d'Adages et de Colloques, des extraits de plusieurs traités, du De Pueris Instituendis au Ciceronianus, et un choix de lettres), p. 373. Daqui por diante, quando me referir a esse texto, citarei, no corpo do texto, entre parênteses.

5 ROUANET, Luiz P. 2000. p. 98. “[...] Erasmo nunca pensou em deixar de apoiar Roma; não via razões suficientes para isso, não encontrava na causa luterana motivos suficientes para ser supliciado. Erasmo era também um hedonista, ou melhor dizendo, um epicurista, e não se julgava capaz de resistir à tortura. Precisaria ter razões muito fortes para se arriscar desse modo, e nunca simpatizou com o extremismo dos partidários de Lutero" HUIZINGA, J. Erasmo. Trad. José Luis Borges Coelho. Lisboa: Portugália, 1970, p. 302 e passim. 
Não irei aqui deter-me na exposição da filosofia estóica, que supera o tema a que me propus, mas indico o excelente trabalho de Rachel Gazolla de Andrade, O ofício do sábio estóico (ANDRADE, 1999).

Consideremos, voltando ao texto de Erasmo, a primeira definição, ou descrição, que apresenta do pensamento epicurista: "Esse filósofo situa a felicidade do homem na volúpia. A vida mais feliz seria aquela que conta mais prazeres e menos tristeza" (p. 373). Não está claro que se possa atribuir essa tese a Epicuro, mas discutirei isto posteriormente. Por ora, basta assinalar que não se sabe quais as fontes de que se utiliza Erasmo para referir-se ao pensamento de Epicuro. De modo geral, sua visão parece bastante acurada. Segundo João Quartim de Moraes, foi somente em 1649 que Pierre Gassendi publicou o texto comentado e explicado das três cartas de Epicuro que chegaram até nós. ${ }^{6}$ Apesar da grande onda de traduções ocorrida no Renascimento, justamente na época de Erasmo, Epicuro foi um dos últimos a ter sua obra editada. É possível que sua informação venha basicamente das mesmas fontes de que dispomos hoje, basicamente Diógenes Laércio e Lucrécio. Seu contato com os humanistas italianos pode ter lhe propiciado entrar em contato com outras fontes que não chegaram até nós, mas trata-se apenas de suposição. Não há nada que corrobore essa afirmação. Pode ser, ainda, que seu conhecimento da doutrina de Epicuro seja apenas indireto.

O que surpreende no texto de Erasmo, e seu interlocutor manifesta essa surpresa, é a ligação que Hedon estabelece entre o epicurismo e o cristianismo, como na seguinte frase: "Se examinamos de mais perto, os maiores epicuristas são os cristãos que levam uma vida santa" (p. 374). É interessante reproduzir a reação de Espudeus, que compara os cristãos aos cínicos, pelo seu modo de vida:

ESPUDEUS: Os cristãos se assemelham aos cínicos. Eles se mortificam graças aos jejuns e se lamentam sobre seus pecados. Ou são pobres, ou se tornam tais por suas generosidades em relação aos indigentes. Os poderosos os oprimem, são alvo de escárnio por parte da maioria. Se o prazer traz a felicidade, esse gênero de vida me parece a cem léguas dos prazeres. (p. 374).

Que não se ponha em questão o cristianismo de Erasmo. Aqui, trata-se de uma crítica à manifestação exterior de religiosidade, típica dos alumbrados e de outras seitas laicas ou monásticas. É preciso lembrar que

${ }^{6}$ MORAES, João Q. 1998. p. 79. 
Erasmo é adepto da devotio moderna, ou devoção interior, que se contrapõe a essa ostensividade. ${ }^{7}$ Além disso, essa observação se encontra na boca de seu adversário, a supor-se que Hedon represente melhor o seu próprio pensamento. Por fim, adiante, Hedon irá defender esse modo de vida como mais sábio do que o que se lhe opõe. Na verdade, a argumentação de Hedon visa justamente convencer Espudeus de que o cristianismo segue, em essência, o espírito do epicurismo.

Para tornar essa adaptação plausível, Hedon aproxima a vida de ascetismo e mortificações dos cristãos à verdadeira volúpia, como apreende bem Espudeus: "Vivem então na volúpia aqueles que Cristo chama de 'bemaventurados' [felizes] porque eles choram?" (p. 375). ${ }^{8}$ A volúpia, redefinida, encontra-se apenas em um espírito saudável: "a verdadeira volúpia só reside em um espírito sadio" (p. 375). A transmutação continua, agora detendo-se sobre a noção de prazer, conferindo-lhe uma conotação platônica "O que é, com efeito, o prazer? Será um prazer autêntico aquele que não provém dos bens verdadeiros, mas de sua sombra enganadora?" (p. 378). E pouco depois, continua o mesmo Hedon: "Portanto, a menos que se viva de maneira piedosa, ou seja, gozando dos verdadeiros bens, ninguém leva uma vida de delícias. Ora, somente a piedade proporciona ao homem a felicidade, pois apenas ela une o homem a Deus, fonte do soberano bem" (p. 378). E por fim: "o verdadeiro prazer é aquele que experimenta uma alma sadia" (ibidem).

Aquele que busca o verdadeiro bem, por exemplo, evita as grandes bebedeiras, o que, de fato, está de acordo com a doutrina de Epicuro (p. 379). Retomando outros topoi do pensamento antigo, combinados com o pensamento cristão, Erasmo discorre sobre a velhice e a tranquiilidade da alma. Diz Hedon: "A única coisa a sustentar essa idade é a lembrança de uma existência pura e a esperança de uma vida melhor. Estes são os dois bastiões da velhice" (p. 381).

Quanto à pobreza, somente é "verdadeiramente pobre quem é desprovido de toda virtude e cuja alma, assim como o corpo, estão destinados ao inferno" (p. 381). Reafirma, em seguida, a crença na Escritura: “A Escritura, que é realmente irrefutável, afirma mais de uma vez que o coração do homem piedoso é o templo de Deus" (p. 382). ${ }^{9}$

7 Discuto aspectos da devotio moderna em minha tese, citada, e remeto, para os "alumbrados", para o livro monumental de BATAILLON, Marcel. Erasmo y España. Tradução de Antonio Alatorre. México: Fondo de Cultura Económica, 1996, p. 166 e seguintes.

8 Referência a Mt 5, 5.

9 "Acaso não sabeis que sois o templo de Deus e que o espírito de Deus habita em vós?" (1Cor $3,16)$. 
Não poderia faltar a defesa da alma como superior ao corpo. Sempre na boca de Hedon: "A alma, com efeito, ainda que ligada a um corpo mortal, é de uma essência mais forte do que ele, o que a torna capaz de transformar de certa maneira o corpo nela mesma, sobretudo se uma energia espiritual se acrescenta a essa força inata" (p. 382).

Efetua-se, também, um elogio da vida contemplativa, como na seguinte passagem: "Pode-se imaginar espetáculo mais magnífico do que a contemplação do nosso universo? Os homens amados de Deus usufruem disso muito mais do que os outros" (p. 384-385).

Sobre os prazeres da carne, a posição de Hedon se aproxima efetivamente daquela de Epicuro: "o charme dos banquetes não reside no luxo da mesa ou nos temperos dos cozinheiros. Depende da saúde e do apetite dos convivas" (p. 385).

Sobre o casamento, diz Hedon, ecoando a formação religiosa de Erasmo: "a união carnal com a esposa é tanto mais doce quanto é rara" e "a união carnal é apenas a menor parte do prazer, que se encontra bem mais na vida comum contínua, que apreciam melhor do que qualquer um aqueles que se amam reciprocamente com uma afeição cristã sincera e igual" (p. 386).

$\mathrm{Na}$ fase conclusiva do colóquio, Hedon resume sua argumentação: "Se ser epicurista consiste em viver nos prazeres, ninguém merece mais esse nome do que os homens que levam uma vida santa e piedosa" (p. 386). A argumentação convenceu seu interlocutor, Espudeus, ao que parece, pois este afirma: "Três vezes feliz, penso eu, aqueles que preservaram sua juventude das máculas e que alcançaram a velhice com um zelo religioso cada vez maior!" (p. 388). Para terminar, Hedon e Espudeus discutem se, chegada a velhice, e tendo a vida sido maculada pelos pecados da juventude, cabe recorrer à misericórdia divina. Nunca é tarde, diz Hedon, tudo dependendo da intensidade da prece, ecoando, mais uma vez, as palavras de Epicuro: "Ninguém, com efeito, é ainda imaturo ou já está demasiado maduro para cuidar da saúde da alma. Quem diz não ter ainda chegado ou já ter ela passado, fala como quem diz não ter ainda chegado ou já ter passado a hora de ser feliz". ${ }^{10}$

10 Epicuro, Carta a Menequeu apud MORAES, João Q. de. 1998. p. 7. 


\section{O epicurismo}

Exporei aqui, rapidamente, em linhas gerais, o pensamento de Epicuro, apenas com a finalidade de examinar o epicurismo de Erasmo. ${ }^{11}$

O epicurismo, baseado em seu fundador, Epicuro (ca. 341 a. C.270 a.C.), ${ }^{12}$ contrapõe-se, quase ponto por ponto, ao estoicismo. Contrariamente à ética rigorista e que privilegia a parte espiritual do homem, o epicurismo prega uma interação entre o corpo e a alma, e tem como fim a felicidade. Nesse sentido, o sábio não deve abster-se do prazer dos sentidos. Não é, porém, uma moral hedonista, isto é, que defende o prazer acima de tudo, como valor positivo. O maior prazer, para os epicuristas, é a abstenção da dor. Nesse sentido, deve ser buscada a moderação, a temperança, pois aos grandes prazeres sucedem-se as grandes dores. O fim da filosofia, para os epicuristas, seria proporcionar quatro "grandes remédios":

1) libertar os homens do temor dos deuses, demonstrando que, pela sua natureza feliz, estes não se ocupam das coisas humanas;

2) libertar os homens do temor da morte, demonstrando que ela não é nada para o homem: "quando nós existimos, não existe a morte; quando a morte existe, não existimos nós";

3) demonstrar a acessibilidade do limite do prazer, isto é, o alcançar fácil do próprio prazer;

4) demonstrar a distância do limite do mal, isto é, a brevidade e a provisoriedade da dor. ${ }^{13}$

Restaram poucos fragmentos dos textos de Epicuro, mas a obra De rerum natura (A natureza das coisas), de Lucrécio, constitui uma descrição apropriada dos princípios fundamentais de sua doutrina. Outra fonte valiosa é a obra de Diógenes Laércio, Vidas e sentenças dos homens ilustres. ${ }^{14}$

11 O texto que se segue baseia-se em apostilas por mim preparadas e utilizadas em aulas. Embora tenha consultado, para a preparação deste artigo, o livro de João Quartim de Moraes, estas anotações são anteriores à leitura de seu livro. De qualquer modo, sempre que este for utilizado, será citado, bem como minhas demais fontes.

12 Não entrarei aqui na discussão sobre a datação do nascimento de Cristo. Trata-se de uma convenção, e a data é aproximada, dada a modificação ocorrida na passagem do calendário romano ao gregoriano.

13 ABAGNANNO, N. História da filosofia, col. II, 4. ed.. Trad. António Borges Coelho. Lisboa: Presença, 1992, p. 36.

14 LAËRCE, Diogène. Vie, doctrines et sentences des philosophes illustres, II. Trad., notices et notes par Robert Genaille. Bourges: Garnier-Flammarion, 1965.

Rev. Filos., v. 19, n. 24, p. 35-45, jan./jun. 2007 
Entre outras coisas, defendeu a naturalidade da linguagem, isto é, que ela é intrínseca aos homens, tese defendida mais tarde por Rousseau. Também deu sua adesão à doutrina atomista, embora tivesse divergências com Demócrito, principal defensor dessa teoria.

Para terminar este breve resumo, vale enfatizar o caráter da ética epicurista. Para Epicuro, "o cume do prazer é a simples e pura destruição da dor". ${ }^{15}$ O ideal do sábio é a ataraxia, ou ausência de preocupação, e aponia, ausência de dor. Consoante com isso, defendia que o filósofo devia se abster e mesmo "fugir" da vida política, pois esta seria fonte de preocupação e, portanto, perturbação. ${ }^{16}$

\section{É possível conciliar epicurismo e cristianismo?}

A aproximação que efetua Erasmo entre epicurismo e cristianismo causa, à primeira vista, estranheza. Em primeiro lugar, porque Epicuro se opunha à utilização constante que faziam seus contemporâneos da religião, intervindo esta nos assuntos políticos cotidianos e ajudando na tomada das decisões. Obviamente, tratava-se de outra religião e outros deuses que não o cristão, mas a essência do argumento parece valer. Assim, neste ponto, bem como nos outros três grandes remédios, a doutrina epicurista parece opor-se simetricamente à doutrina cristã, que encontra maiores afinidades com o pensamento platônico e estóico.

O maior, se não único, ponto de aproximação entre o epicurismo e o cristianismo, é a imagem do jardim, seja o jardim do filósofo, seja o Éden, e a idéia de que devemos cultivar o jardim (Voltaire!). Nas palavras de Quartim de Moraes:

O importante é que um jardim, tenha ele as dimensões de um claustro fechado ou de um amplo parque, configura o mais harmonioso equilíbrio da natureza orgânica e da imaginação artística. O ideal bíblico de felicidade não encontrou melhor expressão do que o Éden, jardim primordial vedado aos humanos pelo pecado de Adão e Eva. ${ }^{17}$

15 Apud Abagnnano, 1992. p. 42.

16 Idem, ibidem.

17 MORAES, João Q. de. 1998, p. 13. 
E mais à frente:

Pode-se comparar a vida no Jardim a um monastério, no qual, entretanto, a única fé era a da felicidade possível para a condição humana. Os que ali viviam, mais do que meros correligionários, eram estranhamente amigos. Eram, sobretudo, portadores de um ideal generoso: voltando as costas ao patriotismo estreito da pólis, inscreviam-se na tendência, que poucos séculos mais tarde seria canalizada pelo cristianismo nascente, à afirmação da fraternidade humana, portanto do cosmopolitismo, entendido como cidadania universal. ${ }^{18}$

Mas, haverá, além dessa similaridade episódica, outros pontos de aproximação? Busca-se, sim, no cristianismo, a paz da alma, mas procura-se evitar a dor. Ora, o mártir (testemunha), pelo contrário, busca, ou pelo menos não foge da dor. ${ }^{19}$ Erasmo está ciente disso, como expressa pela boca de Espudeus: "Tu nos apresentas um paradoxo mais paradoxal do que todos os dos estóicos. Vivem então na volúpia aqueles que Cristo chama de 'bemaventurados' [felizes] porque eles choram?". ${ }^{20}$ Toda a argumentação de Hedon visa desmantelar esse paradoxo, e tornar aceitável a conciliação entre o modo de vida epicurista, que era o seu próprio, e o cristianismo, fé à qual também aderia com sinceridade.

Último colóquio escrito por Erasmo, verdadeira profissão de fé, O epicurista tem por objetivo mostrar que é possível combinar os dois modos de vida, como o fez o próprio Erasmo. Sua vida, na prática, constitui uma comprovação melhor do que o próprio argumento, cuja demonstração exige do filósofo um tour d'addresse (habilidade) todo especial. Lembremos um pouco da biografia de Erasmo.

Nascido por volta de 1467, em Gouda, na Holanda, recebe a educação típica da época, com noções de música e religião. Passou algum tempo entre os Frades da vida comum, que lhe deixou, pelo resto da vida, uma aversão pelo rigorismo e pelo ascetismo. Estes frades não se alimentavam de carne. Aos 17 anos, com a morte de seu pai, seus tutores lhe encaminham, após dois anos estudando em uma escola medíocre, juntamente com seu irmão, para a vida religiosa. Quando se convence de que esta vida não lhe convinha, aproveita a primeira oportunidade, que é servir de secretário a um bispo em viagem, para

18 MORAES, João Q. de. 1998, p. 14.

19 Cf., por exemplo, 2Cor 11, 23-30.

20 L'épicurien, op. cit., p. 375. 
sair do mosteiro, para onde jamais regressaria. Bem mais tarde, será desobrigado de seus votos pelo Papa.

Erasmo sempre combateu a vida monástica, como ilustra sua célebre máxima Monachatus non est pietas (a vida monástica não é religião), sendo sua bête noire. Não se opõe, porém, a outros tipos de vida religiosa, incluindo as ordens mendicantes.

Foi grande tradutor, tendo colaborado para a tradução e edição de uma versão do Novo Testamento (1512-1516). Jamais renegou o cristianismo católico, embora tenha sido crítico do Papa e do Vaticano. Corresponde-se com Lutero, mas se recusa a aderir ao Protestantismo, pois "não suportaria ser torturado por questão de fé". Esta recusa, porém, é sincera. Por mais que critique os costumes da Igreja romana, jamais renuncia a sua crença. Esta, porém, consiste na devotio moderna, uma comunhão entre o indivíduo e Deus, sem manifestação exterior ostensiva.

Erasmo viveu em Paris durante sua juventude, e começou nessa época a colecionar os Adágios, que comentava, e dos quais imprimiu várias edições, e também os colóquios, obras de rara elegância e humor, nos quais manifesta-se seu epicurismo cristão, como nos colóquios "O banquete religioso", ou "O banquete dos contadores de histórias". Dedica, ainda, um opúsculo ao "Vinho da borgonha". Erasmo era um bon vivant, nos limites de sua fé cristã. Jamais entraria para algo de que não pudesse se arrepender depois, como um casamento, uma religião ou um partido.

\section{Conclusão}

Erasmo demonstrou, com sua vida, a possibilidade da conciliação entre epicurismo e cristianismo. A demonstração dessa conciliação é mais delicada, embora tenha procurado fazê-lo em seus escritos, especialmente naquele que examinamos, $O$ epicurista. Sua filosofia pode contribuir para combater o rigorismo dentro da religião cristã, com seu bom humor e espírito de tolerância. Esta noção de tolerância é ainda fonte de preconceitos, devido à sua atitude de superioridade condescendente em relação a outros credos, mas já constitui uma grande avanço em época de fanatismo e intolerância generalizada.O epicurismo, com sua moderação, apreciação dos prazeres da vida, mas também com sua exortação ao cultivo da alma, constitui excelente remédio para todos os tipos de intolerância. 
Há aspectos da filosofia epicurista que não podem ser conciliados com o cristianismo, a começar pela própria idéia de religião, ou temor a Deus, a negação da imortalidade da alma. Outros aspectos, porém, podem ser combinados, como a busca da ataraxia e a defesa de uma cidadania cosmopolita, universal. A fim de compreender melhor a filosofia de Erasmo, e a tentativa de conciliação entre epicurismo e cristianismo, seríamos obrigados a percorrer outras obras suas, como o Manual do soldado cristão (Enchiridion militis christiani).

\section{Referências}

ABAGNANNO, N. História da filosofia. 4. ed. Tradução de António Borges Coelho. Lisboa: Presença, 1992. Col. II.

ANDRADE, Rachel G. de. O ofício do sábio estóico: o duplo registro do discurso da Stoa. São Paulo: Loyola, 1999.

BATAILLON, Marcel. Erasmo y España. Tradução de Antonio Alatorre. México: Fondo de Cultura Económica, 1996.

ERASME. Érasme: Oeuvres, C. Blum, A. Godin, J. C. Margolin, D. Ménager, Paris, Laffont, "Bouquins", 1992 (contient l'Éloge de la Folie, un choix d'Adages et de Colloques, des extraits de plusieurs traités, du De Pueris Instituendis au Ciceronianus, et un choix de lettres).

HUIZINGA, J. Erasmo. Tradução de José Luis Borges Coelho. Lisboa: Portugália, 1970.

LAËRCE, Diogène. Vie, doctrines et sentences des philosophes illustres. Trad. notices et notes par Robert Genaille. Bourges: Garnier-Flammarion, 1965.

MORAES, João Q. de. Epicuro: as luzes da ética. São Paulo: Moderna, 1998.

ROUANET, Luiz P. O enigma e o espelho: uma análise dos discursos sobre a paz de Erasmo e Rawls. 2000. Tese (Doutorando de Filosofia) - FFLCH-USP. 
